\section{September 1985}

The Editor

Results of Ballot on Affiliate Membership August 1985

I read with great disappointment the results of the ballot that would make technicians and technologists eligible for active membership in the $\mathrm{CIF}$. The $\mathrm{CIF}$ cannot afford to exclude any group of people that concern themselves with Canada's forest resources.

I believe forestry has been divided into too many clubs, groups and associations. Our efforts are becoming more fragmented rather than combined and focused. And now, just as I was beginning to think there was a chance of bringing together more people concerned with Canada's forests, 633 people decided they were not welcome in our club. As far as I'm concerned, technicians and technologists are welcome in the CIF and their membership is something we must continue to strive for. There is only strength in numbers and together we will be more effective.

Rick Rhem, RPF 149 Hill St. S.

Thunder Bay, Ontario P7B 3V2

September 24, 1985

The Editor

\section{Dear Dr. Place:}

I was astonished to see Dr. Kayll's letter in the August 1985 issue of the Forestry Chronicle. His literary tongue-lashing of Mr. Marek was so strongly worded that I returned to Mr. Marek's letter in the April 1985 issue to see if I had misinterpreted it. In my opinion, I did not. Dr. Kayll has failed to insert the "... to some degree ..." blame assigned to our educational systems by Mr. Marek for problems now being encountered in forestry.

While it is admirable to see Dr. Kayl assume all the weight for our failures on his shoulders (or try to claim absolution, depending on one's perspective in regards to his comments), I do not believe that was Mr. Marek's intent. I assumed that Mr. Marek was criticizing the failure of our universities to encourage the formal discussion of ethics and the moral responsibilities of foresters in their work places.

Although it is a long ten years since I left Dr. Kayll's present faculty and my grey matter may be rapidly fading to black in some areas, I do not recall any course established to discuss the Ontario Professional Foresters Association's (OPFA) or any other similar organization's mandate or Code of Ethics. I recall some discussion arising, not as part of any course format but informally, during Professors Blair and Day's tenures as president of the OPFA. Other insights into the "real world" of forestry were made possible through open discussions at local CIF Section meetings sponsored at the university.

I hope that the CIF remains as a forum for open discussion. To see a Director (and an associated professor) of a School of Forestry making veiled threats in the Forestry Chronicle and intimating that a fellow professional should "shut-up" only serves to strengthen Mr. Marek's arguments. Constructively outlining why he felt Mr. Marek was incorrect in his analysis would have served Dr. Kayll better. Such vehement reaction by a man of Dr. Kayll's position only reduces the credibility of the institution he serves as an island of freethought in the sea of manipulative forestry.

Yours Sincerely

D. MacAlpine, RPF Box 907, Nipigon, Ontario, POT 2J0

\section{1st October 1985}

The Editor

\section{Dear Sir.}

Authors, editors and publishers are generally well advised to ignore reviewers' adverse comments, but I am driven to making an exception of B. Payandeh's review of The Relascope Idea in your issue of August 1985.

As is explained in detail in its Introduction, the book is not simply a 'translation' awkward or otherwise. Your reviewer is the only one known to me who has complained about lack of clarity, and several quite contrary opinions have been recorded by other reviewers. The work described is not difficult but it is complex, and it was often more important to express ideas precisely than to provide easy reading. No doubt there are some minor failures and blemishes, but taking the book as a whole, I think that most interested foresters should be able to read it without the trouble that $\mathrm{Dr}$. Payandeh has experienced.

There appears to be some suggestion in his review that the book can be used to fil in a few gaps left by Husch, Miller and Beers. It certainly aimed much higher than that, and I should be exceedingly disappointed if it did not awaken a new wave of interest in relascope techniques, which have moved on quite a lot since 1972. I find it particularly strange that a reviewer for a Canadian journal does not even mention the important suggestion by lles, on the application of ACS to $\mathrm{CFI}$, that is given prominent treatment in Chapter 10.

Many foresters would want to read Professor Bitterlich's account of his remarkable work, and his view of the way it has been built upon by his colleagues in many countries, even if he had been in some way let down by his editor and publisher, but don't really think he has been.

Yours sincerely,

W. Finlayson

Director, Commonwealth Forestry Bureau South Parks Road, Oxford OX1 3RD UK

Reaction from a field forester -

why aren't there more - Editor

October 30th, 1985

Janet E. Halliwell, Director

Natural Sciences and Engineering

Research Council of Canada

\section{Dear Miss Halliwell:}

The contribution that forestry-based activities has made to the wealth of this Dominion has been enormous, and there is no need for me to quote the ten-digit numbers to substantiate this claim. Nature, on her own, has accumulated this wealth over centuries in tree stems, and with the exploitation of this resource has come the realization that man-made forests will be needed to sustain our greed.

The Canadian forest is extremely diverse in growing conditions; and problems relating to establishment and tending the new forests are unique and specific to relatively small areas. Foresters in some other countries have experience and practices of previous generations to fall back on in order to avoid costly mistakes in manipulating forest ecosystems. We do not have this yet.

Forest research funding and allocation procedures should reflect the high profile forestry has already earned. We urge the NSERC to implement the concept of a separate research grant selection committee for forestry.

Yours truly,

Adolf R. Kokoshke, RPF Planning Forester Clearwater Timber Products Ltd P.O. Box 9

Clearwater, B.C VOE $1 \mathrm{NO}$ 
October 1, 1985

Editor

\section{Dear Sir:}

The letter from L.A. Gravelines published in the August 1985 issue of the Forestry Chronicle requires comment.

Mr. Gravelines correctly points out that the pulp and paper industry and sawmilling industry are not included in the forest industry in the economic accounts, and would have provincial statistical agencies and Statistics Canada compile special tabulations to encompass dependent (or related) manufacturing activities with forestry.

In common with most of the industrialised nations of the world and in accordance with UN guidelines, Statistics Can- ada includes the sawmilling industry and the pulp and paper industry in the manufacturing division of the economic accounts, but as with many other individual industries, documents the statistics separately.

Although industries such as meat and poultry products, fruit and vegetables, dairy products and other food industries are dependent on the agricultural industry, they too are included in manufacturing. Similarly industries which are dependent on mining, quarrying and oil wells such as the primary metal industries, fabricated metal products, the refined petroleum and coal products industries, and chemical products industries are all included in manufacturing.

The point is that there are numerous special tabulations which could be made for the numerous special interest groups which exist in the nation, and in my opinion it is more appropriate for the special interest groups to compile their own special tabulations rather than a provincial or federal statistical agency which provides the statistics for all industries.

Also if such special tabulations are to be used to influence governments in the allocation of resources, then it is in the interest of the public at large that they not be used selectively to distort the relative contributions of all primary and related industries to an economy.

Yours truly, J. Dobie, RPF

Forest Economist, Statistics Canada, Alvin Bldg., 1145 Robson St., Vancouver, B.C. V6E 3W8

Date Section
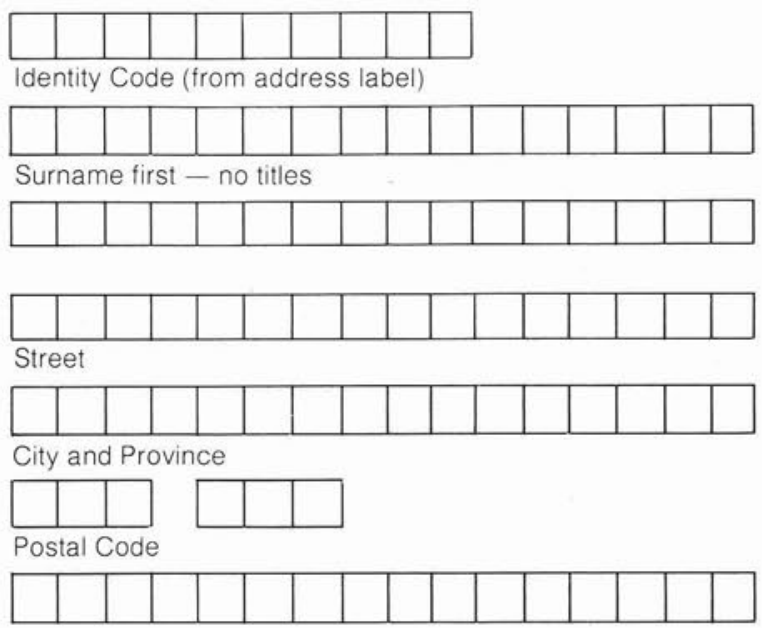